\title{
Performance Pressure of Listed Companies and Environmental Information Disclosure: An Empirical Research on Chinese Enterprise Groups
}

\author{
Peng $\mathrm{Xu}^{1,2}$, Delin Meng ${ }^{1}$, Guiyu Bai ${ }^{3 *}$, Lin Song ${ }^{4}$ \\ ${ }^{1}$ School of Business Administration, Shandong University of Finance and Economics, \\ No. 7366 East Erhuan Road, 250014, Jinan, China \\ ${ }^{2}$ Center for Corporate Governance, Shandong University of Finance and Economics, \\ No. 7366 East Erhuan Road, 250014, Jinan, China \\ ${ }^{3}$ Business School, University of Jinan, No. 13 Shungeng Road, 250002, Jinan, China \\ ${ }^{4}$ Department of Public Administration, Party School of Shandong Provincial Committee of C.P.C \\ (Shandong Academy of Governance), No. 3888 Lvyou Road, 250103, Jinan, China
}

Received: 1 November 2020

Accepted: 17 March 2021

\begin{abstract}
As a non-productive activity, environmental information disclosure is not only a prerequisite for environmental governance and sustainable development of listed companies, but also an effective means for executives to relieve pressure on business performance. Taking Shanghai and Shenzhen A-share listed companies as research samples, the authors have carried out an empirical study to test the relationship between subsidiary performance pressure and environmental information disclosure in enterprise groups, and examines the moderating effect of the parent company's shareholding on the main effect, as well as the differentiation of the moderating effect between high and low degree of executives' synergy allocation level in parent-subsidiary corporations. The results show that: firstly, the performance pressure of listed companies has a positive impact on environmental information disclosure; secondly, the parent company's shareholding will weaken the positive impact of listed company's performance pressure on environmental information disclosure. The higher the parent company's shareholding ratio, the weaker the positive impact of subsidiary company's performance pressure on environmental information disclosure. Thirdly, when the degree of executives' synergy allocation level in parent-subsidiary corporations is low, the negative moderating effect of parent's shareholding ratio is stronger.
\end{abstract}

Keywords: sustainable development, performance pressure, environmental information disclosure, Chinese context

*e-mail: sm_baigy@ujn.edu.cn 


\section{Introduction}

Ecological and environmental issues have always been one of the hotspots in China's economic development. From the $18^{\text {th }}$ National Congress of the Communist Party of China (CPC) to the $19^{\text {th }}$ National Congress of the Communist Party of China (CPC), ecological civilization has been proposed as a millennium plan for the sustainable development of the Chinese nation. The public's understanding of environmental protection concept is deepening day by day, and their expectation of environmental governance of enterprises is also increasing [1-2].

Many studies have shown that, as a non-productive method, environmental information disclosure can convey to the outside world the information that companies have the courage to assume social responsibilities, increase investor favorability [3], shape a good corporate image [4] and enhance corporate value [5-6] In this context, full disclosure of environmental information has become a prerequisite and an important way for listed companies' environmental governance.

In recent years, academic research on corporate environmental information disclosure has been increasing, and fruitful results have also been achieved. The analysis on the influencing factors of environmental information disclosure mainly focuses on the company value [7-8], environmental performance [9-10], profitability [11-12], etc. Clarkson et al. (2013) believe that there is a positive correlation between the quality of environmental information disclosure and the overall value of the company [13]; Meng et al. (2014) found that companies with better and poorer environmental performance tend to disclose more environmental information, the difference is that companies with good environmental performance disclose more substantive information [14]; Nor et al. (2016) argue that corporate profitability is positively related to environmental information disclosure. The stronger the corporate profitability, the higher the level of environmental information disclosure [15].

In short, the existing literature mainly expands and deepens the exploration of the relationship between different factors and environmental information disclosure from the perspectives of legality theory, stakeholder theory, and voluntary information disclosure theory, which enriches the research system of pre-dependent variables of environmental information disclosure. Based on the existing research, the authors analyze the relationship between the performance pressure and disclosure of environmental information of listed companies within the framework of the group, and examines the moderating effect of parent company's shareholding, as well as the difference of the moderating effect in the situation of high and low degree of executives' synergy allocation of parent and subsidiary corporations.

The research contributions of this paper are as follows: First, in recent years, the trend of Chinese enterprises to implement group management has become increasingly obvious, and has gradually become the dominant force in the development of the national economy. This study investigates the regularity of environmental information disclosure when the subsidiary company's operating performance is poor, which can further clarify the governance decisionmaking tendency and behavior logic of the subsidiary company in the governance framework of the parent subsidiary company, and provide reference for the optimization of the governance structure and system design of the parent subsidiary company in practice. Secondly, this study further enriches the research on the antecedent variables of environmental information disclosure of listed companies, tries to explore the motivation and rationality of environmental information disclosure from the perspective of how to alleviate the performance pressure of the senior management of subsidiary companies, and has a deeper understanding of the coping means of the senior management when facing the performance pressure, which can provide reference and support for relevant theories.

\section{Theoretical Analysis and Hypothesis Development}

The impact mechanism of performance pressure of listed companies on environmental information disclosure.

According to the theory of pressure, within the enterprise, the management will face the performance pressure brought by the growth speed of the enterprise. When the growth pressure faced by the management is small, the management will have more power to make the operation decision of the enterprise. When the performance pressure faced by the management is large, the power of their efforts will be reduced, and they may choose to achieve the goal of rapid growth of the enterprise in a non-productive way [16]. The principal-agent theory holds that there is information asymmetry and interest inconsistency between the principal and the agent of an enterprise. In such a situation, the executives of listed companies as agents may make decisions that are beneficial to their own interests based on their own information advantages [17]. Performance pressure reflects how difficult it is for listed companies to achieve performance goals [18]. The principal-agent theory believes that executives of listed companies as agents will make decisions that are beneficial to their own interests based on their own information advantages. Therefore, when the operating status of a listed company is highly related to the personal economic benefits and job stability of the executives, performance pressure will affect the idea and the behavior of the executives. That is, the executives of listed companies will first perceive and evaluate whether the performance goals can be achieved, and will take a series of more 
effective and beneficial actions after weighing the pros and cons [19].

If the performance pressure of a listed company is small, that is, the realization of the expected goal is relatively simple for the executives, and even if the performance pressure is not enough to affect the daily operation of the company, the executives can achieve the expected goal without too much effort. The executives of the listed company will tend to improve operating efficiency by improving internal governance mechanisms and reducing short-term expenditures under the expectations of all parties to achieve the expected goals of executives. However, if the executives of listed companies perceive that it is very difficult to achieve the expected goal, the expected goal is far from the current expected goal, and they cannot improve the performance through the daily management of business in the short term to achieve the goal and relieve the pressure, they will pay less attention to the daily operation and management behavior, that is, they will not pay too much effort for it, but will be more inclined to choose Non-productive activities to transfer the pressure of assessment and evaluation caused by poor performance [20].

In view of the importance of environmental protection and governance in the current corporate development, and the executives have greater discretion and decision-making power on environmental information disclosure [21], they can control the amount, details, and intensity of environmental information disclosure. Therefore, environmental information disclosure provides an opportunity for listed company executives to alleviate the pressure of performance. Executives of listed companies may regard environmental information disclosure as an export of the company's operating performance. Under the circumstances of greater performance pressure, in order to prevent the company from Environmental information disclosure for decline in value and loss of reputation. Based on this, we suggest the following hypothesis:

Hypothesis 1. The performance pressure of listed companies has a positive impact on the level of environmental information disclosure.

The moderating effect of parent company shareholding on the relationship between listed companies' performance pressure and environmental information disclosure.

In the framework of the group, as the controlling shareholder of the listed company, the parent company has the means and motivation to supervise the listed company's business activities [22-23]. When the parent company's shareholding ratio is relatively high, the effect of converging interests with the listed company becomes more obvious, and the awareness and motivation of the supervision of the listed company are also stronger, and compared to other small and medium shareholders' "voting with their feet" and "freeriding" psychology [24-25], the parent company has a deeper understanding of the operating conditions of the listed company, and pays more attention to the longterm interests of the listed company [26]. It also has a stronger ability to identify and control the strategic decisions of listed company executives. The degree of information asymmetry between parent and subsidiary companies is weakened. The operation decisions and implementation goals of listed company are easier to identify and known by the parent company [27]. At this time, the effect of non-productive transfer of pressure by executives of listed companies will be reduced, and the difficulty in achieving the expected effect will lead to the weakening of the motivation of executives to transfer pressure, instead, they will focus more on how to use productive activities to relieve performance pressure. Therefore, based on the above discussion, we propose the following hypothesis:

Hypothesis 2. There is a moderating effect of parent company shareholding on the relationship between listed companies' performance pressure and environmental information disclosure. The specific performance is: the higher the parent company shareholding ratio, the weaker the positive impact of listed company performance pressure on environmental information disclosure.

The influence of executives' synergy allocation level in parent-subsidiary corporations on the parent company shareholding.

Executives' synergy allocation level in parentsubsidiary corporations is a governance mechanism for the parent company to coordinate and centrally configure the listed company executives through concurrent senior management, and it is also an effective way for the parent company to control and interfere with the management decisions of listed companies [28]. The low level of the executives' synergy allocation level means that there are fewer concurrent executives from the parent company in listed companies. Due to the limitation of dual duties, it is difficult to identify and supervise the operating conditions of listed companies in a timely and effective manner [29-30], and it is even more difficult to accurately identify the motivation of the transfer of pressure by the executives of listed companies and the information asymmetry between parent and listed companies is relatively high [31]. At this time, if the shareholding ratio of the parent company is high, the parent company will improve the supervision consciousness and motivation of listed companies in view of the concern about ownership income, especially when the parent company knows that it has a small number of concurrent executives in listed companies, it will also improve the recognition ability of executives' decision-making of listed companies for the sake of stabilizing its own control rights and improving the earnings value of listed companies. Correspondingly, the executives of listed companies have been intensified under the supervision of the parent company, and the effect of transferring performance pressure through the non-productive 


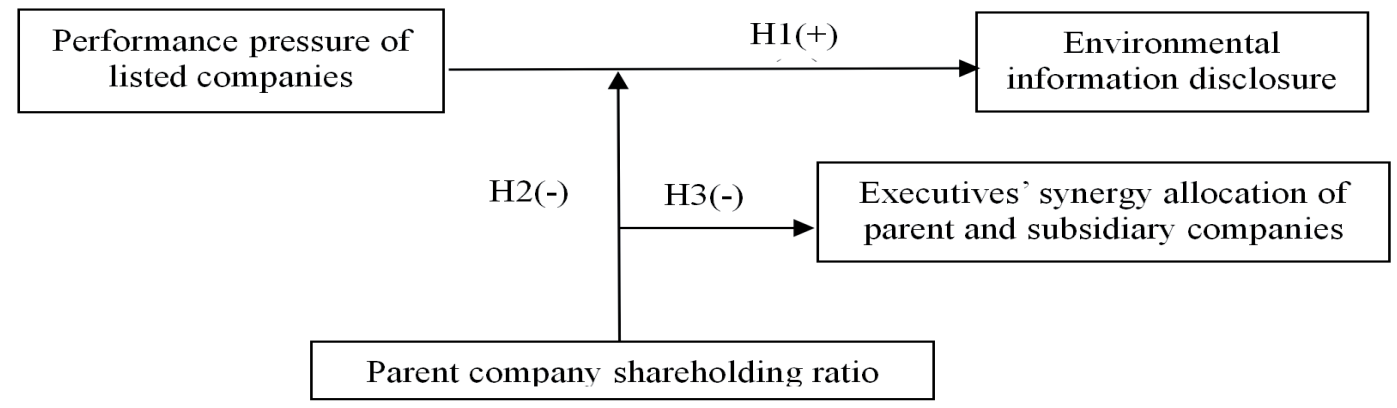

Fig. 1. Hypothesized model.

activity of environmental information disclosure is not good. On the contrary, it will improve the standardization of decision-making behavior and tend to relieve performance pressure through formal productive behavior. Based on the above analysis, the following hypothesis is put forward:

Hypothesis 3. Executives' synergy allocation level in parent-subsidiary corporations will influence the moderating effect of parent company's shareholding, specifically as follows: under the situation of low level of executives' synergy of parent and subsidiary companies, the stronger the weakening effect of parent company's shareholding on the positive correlation between performance pressure of listed companies and environmental information disclosure. The overall study model is shown in Fig. 1.

\section{Methodology and Variable Definitions}

\section{Methodology}

In this paper, the quantitative regression analysis method is adopted, and the data are analyzed by using stata15.1 software. This paper takes the listed manufacturing companies in Shanghai and Shenzhen stock markets as the initial sample, and further selects them through the following steps: First, they belong to enterprise groups; Second, during the sample observation period, "2014-2017" did not have major restructuring phenomena such as changes in controlling shareholders; Third, the sample enterprises with serious lack of ST (Special Treatment) and data are eliminated. Finally, 3092 groups of samples were obtained, includes data of 773 listed manufacturing companies in China from 2014 to 2017, and other relevant data used in the empirical analysis of this paper mainly came from the CSMAR database. (CSMAR database is an economic and financial database developed from the needs of academic research).

\section{Variable Definitions}

(1) Environmental Information Disclosure (EDI). This paper draws on the research of Wiseman (1982) and assigns values to environmental information disclosure indicators [32]. The value is evaluated according to three aspects: "whether the environmental information is disclosed in accordance with the GRI Sustainability Reporting Guidelines", "whether to disclose environmental and sustainable development information", and "whether to disclose social responsibility system construction and improvement measures", which meets one condition Recorded as "1", otherwise as " 0 ".

(2) Performance pressure (PP). This article refers to the method of Gomes (1998) and uses the reverse index and uses the following method to calculate [33]:

$$
P P=P_{i}-\alpha H A_{i}-(1-\alpha) S A_{i}
$$

...where $\mathrm{P}_{\mathrm{i}}$ is the return on total assets (ROA) of the $\mathrm{i}$ company this year, $\mathrm{HA}_{\mathrm{i}}$ is the historical performance of the $\mathrm{i}$ company, and $\mathrm{SA}_{\mathrm{i}}$ is the average performance of the industry in which the i company belongs this year, and $\alpha$ is the weight. Based on the previous research [34], it is assigned a value of 0.5 . The smaller the value, the more serious performance pressure the company are facing.

(3) The parent company shareholding ratio (EC). The parent company's shareholding ratio refers to the previous research [35] and is measured by the largest shareholder's shareholding ratio.

(4) Executives' synergy allocation of parent and subsidiary corporations. Executives' synergy allocation of parent and subsidiary corporations reflects the governance mechanism adopted by the corporate group operation to achieve unified coordination and centralized configuration of the senior management within the group. Based on the previous research [36] and the operation environment of China, this paper uses the ratio of the number of subsidiary executives concurrently serving as executives in parent company to the total number of subsidiary executives to measure and divides them into two groups according to the median of the calculated ratio. The group above the median is considered as a high degree of synergy allocation, while the group below the median is considered as a low degree of synergy allocation. 
Table 1. Definition and measurement of variables.

\begin{tabular}{|c|c|c|}
\hline Variables & Code & Index \\
\hline $\begin{array}{l}\text { Environmental information } \\
\text { disclosure }\end{array}$ & EDI & $\begin{array}{l}\text { Whether to disclose environmental information according to GRI Guidelines for } \\
\text { Sustainable Development Report, whether to disclose environmental and sustainable } \\
\text { development information, and whether to disclose the construction and improvement } \\
\text { measures of social responsibility system. If meets one condition, it is recorded as } 1 \text {, } \\
\text { otherwise it is recorded as } 0 \text {, and finally forms } 0-3 \text { discrete data. }\end{array}$ \\
\hline Performance pressure & PP & $\begin{array}{l}\text { The performance of the listed company this year is subtracted from the average } \\
\text { performance and historical performance of the industry after assignment. }\end{array}$ \\
\hline $\begin{array}{l}\text { Shareholding ratio of parent } \\
\text { company }\end{array}$ & $\mathrm{EC}$ & $\begin{array}{c}\text { The number of shares held by the parent company accounts for the proportion } \\
\text { of the total equity of the listed company. }\end{array}$ \\
\hline $\begin{array}{l}\text { Executives' synergy } \\
\text { allocation of parent and } \\
\text { subsidiary corporations }\end{array}$ & Synergy & $\begin{array}{l}\text { Measured by the ratio of the number of subsidiary executives concurrently serving } \\
\text { as executives in parent company to the total number of subsidiary executives, and } \\
\text { divides them into two groups according to the median of the calculated ratio. }\end{array}$ \\
\hline Company size & Size & The natural logarithm of the total assets of a listed company at the end of the year. \\
\hline Board leadership structure & BLS & $\begin{array}{l}\text { Measured as follows: Part-time situation of chairman and CEO. When two positions } \\
\text { were held by one person, this indicator was marked as "1", otherwise this indicator } \\
\text { was marked as "0". }\end{array}$ \\
\hline $\begin{array}{l}\text { Environmental protection } \\
\text { investment in the province }\end{array}$ & Province & $\begin{array}{l}\text { Measured according to the amount of environmental protection expenditure of each } \\
\text { province. }\end{array}$ \\
\hline Board independence & IND & $\begin{array}{l}\text { The number of shares held by the parent company accounts for the proportion of the } \\
\text { total equity of the listed company. }\end{array}$ \\
\hline Audit fee & Audit & The audit fee divided by the total assets at the end of the period. \\
\hline Board shareholding ratio & BS & $\begin{array}{l}\text { The number of shares held by the board of directors' accounts for the proportion of } \\
\text { the total share capital of the listed company. }\end{array}$ \\
\hline $\begin{array}{l}\text { Remuneration levels of } \\
\text { directors, supervisors, and } \\
\text { executives }\end{array}$ & Payment & $\begin{array}{l}\text { The total remuneration of the board of directors, the board of supervisors and the } \\
\text { senior management is divided by the operating cost of the listed company that year. }\end{array}$ \\
\hline Year (2015) & Y1 & Observation year belongs to this year, recorded as 1 , not 0 . \\
\hline Year (2016) & Y2 & Observation year belongs to this year, recorded as 1 , not 0 . \\
\hline Year (2017) & Y3 & Observation year belongs to this year, recorded as 1 , not 0 . \\
\hline
\end{tabular}

(5) Control variables. Combined with the existing research, this paper also selects the following factors that reflect the characteristics of listed companies as control variables: company size, leadership structure of board of directors (because of the difference of data magnitude, we take logarithm of the original data of the indicator in empirical analysis. Board leadership structure is measured as follows: Parttime situation of chairman and CEO. When two positions were held by one person, this indicator was marked as "1", otherwise this indicator was marked as " 0 ".), environmental protection investment in the province, audit fees, shareholding ratio of board of directors, and high salary level of directors [37-38]. Definition and measurement of variables are shown in Table 1.

\section{Models}

To investigate the hypothesis of this paper, the following multiple regression model is designed:

$$
E D I=c+\sum_{j=1}^{10} b_{j} \text { Control }+P P+\varepsilon
$$

$$
E D I=c+\sum_{j=1}^{10} b_{j} \text { Control }+P P+E C+P P \times E C+\varepsilon
$$

$$
E D I=c+\sum_{j=1}^{10} b_{j} \text { Control }+P P+E C+P P \times E C+\varepsilon
$$

(Synergy $>$ Median)

$$
E D I=c+\sum_{j=1}^{10} b_{j} \text { Control }+P P+E C+P P \times E C+\varepsilon
$$

(Synergy $<$ Median)

Control is the control variable group, $\mathrm{c}$ is the intercept term, $\varepsilon$ represents the random disturbance 
Table 2. Descriptive statistics of variables (means, standard deviations, and correlation coefficients of major variables).

\begin{tabular}{|c|c|c|c|c|c|c|c|c|c|}
\hline Index & EDI & PP & EC & Size & BLS & Audit & Province & BS & Payment \\
\hline Variable & 3092 & 3092 & 3092 & 3092 & 3092 & 3092 & 3092 & 3092 & 3092 \\
\hline Mean & 0.402 & 0.001 & 0.363 & 22.49 & 0.196 & 0.001 & 4.780 & 0.027 & 0.002 \\
\hline $\begin{array}{c}\text { Standard } \\
\text { Deviation }\end{array}$ & 0.681 & 0.062 & 0.138 & 1.207 & 0.397 & 0.000 & 3.179 & 0.077 & 0.005 \\
\hline Median & 0 & -0.004 & 0.348 & 22.35 & 0 & 0 & 4 & 0.001 & 0.008 \\
\hline Minimum & 0 & -0.679 & 0.050 & 19.23 & 0 & 0 & 1 & 0 & 0 \\
\hline Maximum & 3 & 1.850 & 0.900 & 27.31 & 1 & 0.003 & 21 & 0.744 & 0.183 \\
\hline
\end{tabular}

term, $\mathrm{j}$ is the number of each control variable, and $b_{j}$ represents the regression coefficient of each control variable. Model 1 is a regression model of the performance pressure of listed companies on environmental information disclosure, which can test hypothesis H1; On the basis of model 1, model 2 adds the interactive terms of performance pressure and parent company's shareholding ratio, which is used to analyze the moderating effect of parent company's shareholding on the impact of listed company's performance pressure on environmental information disclosure, and can verify hypothesis H2; Model 3 and Model 4 respectively test the moderating effect of parent company's shareholding on the main effect in the context of high and low executives' synergy allocation of parent and subsidiary corporations, and compare the regression coefficients and significance of the interaction between parent company's shareholding ratio and performance pressure in the two models, so as to judge the influence of executives' synergy allocation of parent and subsidiary corporations on parent company's shareholding and verify hypothesis $\mathrm{H} 3$.

\section{Data Analysis and Results Discussion}

\section{Descriptive Statistics}

Table 2 reports the mean, median, standard deviation, minimum and maximum values of the main variables. The average value of environmental information disclosure is less than 0.5 , the median is 0 , and the standard deviation is large, it can be seen that that due to the lack of standardization and compulsory environmental information disclosure of listed companies, the level of information disclosure among samples varies, and the environmental information of some listed companies The level of information disclosure is low; there is a significant gap between the minimum and maximum performance pressure indicators, indicating that the performance pressures of different companies in the same industry are quite different; the average and median of the parent company's shareholding ratio are both about 0.3 and the standard deviation It is also small, reflecting that the gap in the shareholding ratio of the parent company is relatively small; the mean value of the dummy variable of the chairman and general manager concurrently is small, and the standard deviation is large, which shows that there are relatively few cases of combining two positions in the sample companies; The large input standard deviation indicates that there is a clear gap in the level of local environmental protection expenditures between provinces.

\section{Multiple Regression Results}

According to the model designed above, use stata14.0 software to perform regression analysis. The specific calculation results are shown in Table 3. The regression analysis result of model M1 shows that after controlling for various factors that may affect environmental information disclosure, the regression coefficient of listed company performance pressure is negative ( $\beta=-0.094)$, which is significant at the $10 \%$ level. Due to performance pressure adopts reverse indicators, it shows that the performance pressure of listed companies has a positive impact on the level of environmental information disclosure. That is, the greater the performance pressure of listed companies, the more likely it is to disclose environmental information at a higher level. Thus, H1 is verified. The analysis result of the model M2 shows that the regression coefficient of the parent company's shareholding ratio and the performance pressure interaction term of the listed company is positive $(\beta=0.137)$, and it is significant at the basic level of $5 \%$, this shows that the parent company's shareholding has a significant moderating role in the relationship between the performance pressure of listed companies and environmental information disclosure. Combined with the coincidence of main effect and interactive term coefficient, it can be judged that the higher the parent company's shareholding ratio, the weaker the positive impact of listed companies' performance pressure on environmental information disclosure. Hypothesis $\mathrm{H} 2$ is verified. From the analysis results of models M3 and M4, it can be seen that in the case of a low degree of executives' synergy allocation of parent and subsidiary corporations, the regression coefficient of the parent company's shareholding ratio 
Table 3. Regression results analysis.

\begin{tabular}{|c|c|c|c|c|}
\hline \multirow[t]{2}{*}{ Variables } & \multicolumn{4}{|c|}{ EDI } \\
\hline & M1 & M2 & M3 (Synergy>Median) & M4 (Synergy $<$ Median) \\
\hline \multicolumn{5}{|c|}{ Control variables } \\
\hline Size & $\begin{array}{c}1.258 * * * \\
(8.83)\end{array}$ & $\begin{array}{c}1.261 * * * \\
(8.78)\end{array}$ & $\begin{array}{c}1.290 * * * \\
(7.34)\end{array}$ & $\begin{array}{c}1.505^{* * *} \\
(6.84)\end{array}$ \\
\hline BLS & $\begin{array}{l}-0.173 \\
(-0.61)\end{array}$ & $\begin{array}{l}-0.176 \\
(-0.62)\end{array}$ & $\begin{array}{l}0.118 \\
(0.26)\end{array}$ & $\begin{array}{l}-0.405 \\
(-1.12)\end{array}$ \\
\hline Province & $\begin{array}{l}-0.079 \\
(-0.64)\end{array}$ & $\begin{array}{l}-0.082 \\
(-0.66)\end{array}$ & $\begin{array}{l}-0.022 \\
(-0.13)\end{array}$ & $\begin{array}{l}-0.049 \\
(-0.30)\end{array}$ \\
\hline IND & $\begin{array}{l}-0.077 \\
(-0.73)\end{array}$ & $\begin{array}{l}-0.081 \\
(-0.77)\end{array}$ & $\begin{array}{l}0.011 \\
(0.08)\end{array}$ & $\begin{array}{c}-0.247 * \\
(-1.74)\end{array}$ \\
\hline Audit & $\begin{array}{l}-0.083 \\
(-0.74)\end{array}$ & $\begin{array}{l}-0.084 \\
(-0.75)\end{array}$ & $\begin{array}{l}-0.071 \\
(-0.48)\end{array}$ & $\begin{array}{l}-0.088 \\
(-0.57)\end{array}$ \\
\hline BS & $\begin{array}{c}-0.301 * \\
(-1.90)\end{array}$ & $\begin{array}{c}-0.300^{*} \\
(-1.91)\end{array}$ & $\begin{array}{l}-0.150 \\
(-0.64)\end{array}$ & $\begin{array}{c}-0.503^{* *} \\
(-2.05)\end{array}$ \\
\hline Payment & $\begin{array}{c}-0.878^{* * *} \\
(-3.52)\end{array}$ & $\begin{array}{c}-0.892 * * * \\
(-3.58)\end{array}$ & $\begin{array}{l}-0.315 \\
(-0.72)\end{array}$ & $\begin{array}{c}-0.751^{* *} \\
(-2.08)\end{array}$ \\
\hline Year (2015) & Control & Control & Control & Control \\
\hline Year (2016) & Control & Control & Control & Control \\
\hline Year (2017) & Control & Control & Control & Control \\
\hline \multicolumn{5}{|c|}{ Independent variable } \\
\hline PP & $\begin{array}{c}-0.094 * \\
(-1.85) \\
\end{array}$ & $\begin{array}{c}-0.101 * * \\
(-1.96)\end{array}$ & $\begin{array}{l}-0.059 \\
(-0.86) \\
\end{array}$ & $\begin{array}{c}-0.153 * \\
(-1.65) \\
\end{array}$ \\
\hline \multicolumn{5}{|l|}{ Moderator } \\
\hline $\mathrm{EC}$ & $\begin{array}{c}0.502 * * * \\
(3.85)\end{array}$ & $\begin{array}{c}0.522 * * * \\
(3.94)\end{array}$ & $\begin{array}{c}0.408 * * \\
(2.34)\end{array}$ & $\begin{array}{c}0.379 * * \\
(2.11)\end{array}$ \\
\hline \multicolumn{5}{|c|}{ Product term } \\
\hline $\mathrm{EC} * \mathrm{PP}$ & & $\begin{array}{c}0.137 * * \\
(2.19)\end{array}$ & $\begin{array}{l}0.001 \\
(0.01) \\
\end{array}$ & $\begin{array}{c}0.343 * * * \\
(3.46)\end{array}$ \\
\hline $\mathrm{AIC}$ & 3510.07 & 3509.25 & 1980.63 & 1703.73 \\
\hline $\mathrm{N}$ & 3092 & 3092 & 1538 & 1554 \\
\hline
\end{tabular}

Note: Because the environmental information of the explained variable is disclosed as a discrete data variable, the ologit regression analysis method is adopted; ***,**,* indicate the significance level of $1 \%, 5 \%$, and $10 \%$, respectively, and the $\mathrm{z}$-values in parentheses. As the panel ologit model cannot display R square, Akaike Information Criterion (AIC) is adopted to evaluate the fitting degree of this model. The AIC of model M1 is 3510.07, the AIC of M2 is 3509.25, the AIC of M3 is 1980.63, and the AIC of M4 is 1703.73 . The numerical values have all decreased with respect to M1, indicating that the fitting degree of the model in this paper has been improved.

and the performance pressure interaction term of the listed company is positive $(\beta=0.343)$, and it is at $1 \%$ the level is significant, indicating that in the context of a lower degree of executives' synergy allocation of parent and subsidiary corporations, the parent company's shareholding ratio has a stronger weakening effect on the main effect. Hypothesis H3 has been verified; In the case of a high degree of executives' synergy allocation of parent and subsidiary corporations, although the regression coefficient of the interaction term between the parent company's shareholding ratio and the listed company's performance pressure is positive $(\beta=0.001)$, the significance test is not passed. The reason for the analysis may be: At this time, concurrently serving as executives has a strong role in decision-making and supervision of listed company's executives, and can serve as an information communication role to timely feedback the operating status of the listed company to the parent company, so the parent company does not need to pay more attention to it to handle the affairs of listed companies. 
Table 4. Random sample test.

\begin{tabular}{|c|c|c|c|c|}
\hline \multirow[t]{2}{*}{ Variables } & \multicolumn{4}{|c|}{ EDI } \\
\hline & M1 & M2 & M3 (Synergy>Median) & M4 (Synergy $<$ Median) \\
\hline \multicolumn{5}{|c|}{ Control variables } \\
\hline Size & $\begin{array}{c}1.337 * * * \\
(9.28)\end{array}$ & $\begin{array}{c}1.343 * * * \\
(9.24)\end{array}$ & $\begin{array}{c}1.163 * * * \\
(6.43)\end{array}$ & $\begin{array}{c}1.738 * * * \\
(7.67)\end{array}$ \\
\hline BLS & $\begin{array}{l}-0.155 \\
(-0.54)\end{array}$ & $\begin{array}{l}-0.156 \\
(-0.54)\end{array}$ & $\begin{array}{l}0.220 \\
(0.48)\end{array}$ & $\begin{array}{l}-0.328 \\
(-0.82)\end{array}$ \\
\hline Province & $\begin{array}{l}-0.013 \\
(-0.10)\end{array}$ & $\begin{array}{l}-0.016 \\
(-0.11) \\
\end{array}$ & $\begin{array}{l}0.102 \\
(0.56)\end{array}$ & $\begin{array}{l}-0.103 \\
(-0.56)\end{array}$ \\
\hline IND & $\begin{array}{l}-0.133 \\
(-1.27)\end{array}$ & $\begin{array}{l}-0.135 \\
(-1.29)\end{array}$ & $\begin{array}{l}-0.005 \\
(-0.04)\end{array}$ & $\begin{array}{l}-0.249 \\
(-1.61)\end{array}$ \\
\hline Audit & $\begin{array}{l}-0.091 \\
(-0.71)\end{array}$ & $\begin{array}{l}-0.092 \\
(-0.71)\end{array}$ & $\begin{array}{l}-0.162 \\
(-0.85)\end{array}$ & $\begin{array}{l}-0.011 \\
(-0.08)\end{array}$ \\
\hline $\mathrm{BS}$ & $\begin{array}{c}-0.426^{* *} \\
(-2.25)\end{array}$ & $\begin{array}{c}-0.425 * * \\
(-2.23)\end{array}$ & $\begin{array}{l}-0.144 \\
(-0.60)\end{array}$ & $\begin{array}{c}-0.798 * * * \\
(-3.17)\end{array}$ \\
\hline Payment & $\begin{array}{c}-0.731 * * * \\
(-2.58)\end{array}$ & $\begin{array}{c}-0.748 * * * \\
(-2.66)\end{array}$ & $\begin{array}{l}-0.261 \\
(-0.64)\end{array}$ & $\begin{array}{c}-0.698 * \\
(-1.80)\end{array}$ \\
\hline Year (2015) & control & control & control & control \\
\hline Year (2016) & control & control & control & control \\
\hline Year(2017) & control & control & control & control \\
\hline \multicolumn{5}{|c|}{ Independent variable } \\
\hline PP & $\begin{array}{c}-0.100 * \\
(-1.76) \\
\end{array}$ & $\begin{array}{c}-0.115^{*} \\
(-1.85) \\
\end{array}$ & $\begin{array}{l}-0.082 \\
(-0.94) \\
\end{array}$ & $\begin{array}{l}-0.151 \\
(-1.39) \\
\end{array}$ \\
\hline \multicolumn{5}{|c|}{ Moderator } \\
\hline $\mathrm{EC}$ & $\begin{array}{c}0.458 * * * \\
(3.32)\end{array}$ & $\begin{array}{c}0.467 * * * \\
(3.36)\end{array}$ & $\begin{array}{c}0.431 * * \\
(2.38) \\
\end{array}$ & $\begin{array}{l}0.320^{*} \\
(1.65) \\
\end{array}$ \\
\hline \multicolumn{5}{|c|}{ Product term } \\
\hline $\mathrm{EC} * \mathrm{PP}$ & & $\begin{array}{c}0.166^{*} \\
(1.90) \\
\end{array}$ & $\begin{array}{l}0.035 \\
(0.24) \\
\end{array}$ & $\begin{array}{c}0.316^{* *} \\
(2.56) \\
\end{array}$ \\
\hline AIC & 2930.80 & 2930.07 & 1675.94 & 1412.70 \\
\hline $\mathrm{N}$ & 2474 & 2474 & 1227 & 1247 \\
\hline
\end{tabular}

Note: Because the environmental information of the explained variable is disclosed as a discrete data variable, the ologit regression analysis method is adopted; ***,**, * indicate the significance level of $1 \%, 5 \%$, and $10 \%$, respectively, and the $\mathrm{z}$-values in parentheses.

\section{Robustness}

\section{Random Sample}

Considering that the sample size may affect the research results, this paper randomly selects $80 \%$ of the samples for testing. The testing results are shown in Table 4. In Model 1, the regression coefficient between performance pressure and environmental information disclosure is -0.100 , which is significantly negative based on $10 \%$, proving Hypothesis 1 . The results of model 2 show that the regression coefficient of the interaction term between parent's shareholding ratio and performance pressure is 0.166 , which is significantly positive based on $10 \%$. hypothesis 2 is verified. The results of model 3 and model 4 show that in the context of a lower degree of executives' synergy allocation of parent and subsidiary corporations, the regression coefficient of the interaction between parent's shareholding ratio and performance pressure is 0.316 , which is significantly positive based on $5 \%$, and hypothesis 3 is verified. The empirical results are consistent with the above regression conclusions, indicating that the research results are robust after selecting random samples.

\section{Add Control Variables}

In addition, considering that the asset-liability ratio (Lev) that reflects the financial status of the enterprise and the property rights (State-owned) of the listed companies may affect the robustness of the experimental 
Table 5. Add Control Variable.

\begin{tabular}{|c|c|c|c|c|}
\hline \multirow[t]{2}{*}{ Variables } & \multicolumn{4}{|c|}{ EDI } \\
\hline & M1 & M2 & M3 (Synergy>Median) & M4 (Synergy $<$ Median) \\
\hline \multicolumn{5}{|c|}{ Control variables } \\
\hline Size & $\begin{array}{c}1.171 * * * \\
(7.24)\end{array}$ & $\begin{array}{c}1.167 * * * \\
(7.17)\end{array}$ & $\begin{array}{c}1.229 * * * \\
(6.33)\end{array}$ & $\begin{array}{c}1.424 * * * \\
(5.89)\end{array}$ \\
\hline BLS & $\begin{array}{l}0.007 \\
(0.03)\end{array}$ & $\begin{array}{l}0.005 \\
(0.02)\end{array}$ & $\begin{array}{l}0.308 \\
(0.67)\end{array}$ & $\begin{array}{l}-0.162 \\
(-0.44)\end{array}$ \\
\hline Province & $\begin{array}{l}-0.140 \\
(-1.09)\end{array}$ & $\begin{array}{l}-0.142 \\
(-1.11)\end{array}$ & $\begin{array}{l}-0.097 \\
(-0.56)\end{array}$ & $\begin{array}{l}-0.095 \\
(-0.58)\end{array}$ \\
\hline IND & $\begin{array}{l}-0.067 \\
(-0.63)\end{array}$ & $\begin{array}{l}-0.070 \\
(-0.66)\end{array}$ & $\begin{array}{l}0.016 \\
(0.12)\end{array}$ & $\begin{array}{l}-0.229 \\
(-1.62)\end{array}$ \\
\hline Audit & $\begin{array}{l}-0.104 \\
(-0.88)\end{array}$ & $\begin{array}{l}-0.108 \\
(-0.92)\end{array}$ & $\begin{array}{l}-0.098 \\
(-0.63)\end{array}$ & $\begin{array}{l}-0.118 \\
(-0.73)\end{array}$ \\
\hline BS & $\begin{array}{l}-0.143 \\
(-1.07)\end{array}$ & $\begin{array}{l}-0.140 \\
(-1.06)\end{array}$ & $\begin{array}{l}0.111 \\
(0.52)\end{array}$ & $\begin{array}{c}-0.347^{*} \\
(-1.75)\end{array}$ \\
\hline Payment & $\begin{array}{c}-0.737 * * * \\
(-2.99)\end{array}$ & $\begin{array}{c}-0.743 * * * \\
(-3.02)\end{array}$ & $\begin{array}{l}-0.134 \\
(-0.31)\end{array}$ & $\begin{array}{c}-0.580^{*} \\
(-1.72)\end{array}$ \\
\hline Lev & $\begin{array}{l}-0.562 \\
(-0.66)\end{array}$ & $\begin{array}{l}-0.478 \\
(-0.56)\end{array}$ & $\begin{array}{l}-0.871 \\
(-0.92)\end{array}$ & $\begin{array}{l}-0.857 \\
(-0.66)\end{array}$ \\
\hline State-owned & $\begin{array}{c}1.806^{* * * *} \\
(6.10)\end{array}$ & $\begin{array}{c}1.811 * * * \\
(6.11)\end{array}$ & $\begin{array}{c}1.765^{* * * *} \\
(4.50)\end{array}$ & $\begin{array}{c}1.877 * * * \\
(4.56)\end{array}$ \\
\hline Year (2015) & control & control & control & control \\
\hline Year (2016) & control & control & control & control \\
\hline Year (2017) & control & control & control & control \\
\hline \multicolumn{5}{|c|}{ Independent variable } \\
\hline PP & $\begin{array}{c}-0.099^{*} \\
(-1.78)\end{array}$ & $\begin{array}{c}-0.104^{*} \\
(-1.82)\end{array}$ & $\begin{array}{l}-0.067 \\
(-0.93)\end{array}$ & $\begin{array}{l}-0.167 \\
(-1.60)\end{array}$ \\
\hline \multicolumn{5}{|l|}{ Moderator } \\
\hline $\mathrm{EC}$ & $\begin{array}{c}0.487 * * * \\
(3.68)\end{array}$ & $\begin{array}{c}0.504 * * * \\
(3.76)\end{array}$ & $\begin{array}{c}0.373 * * \\
(2.13)\end{array}$ & $\begin{array}{c}0.391 * * \\
(2.12)\end{array}$ \\
\hline \multicolumn{5}{|l|}{ Product term } \\
\hline $\mathrm{EC} * \mathrm{PP}$ & & $\begin{array}{c}0.133 * * \\
(2.13)\end{array}$ & $\begin{array}{l}-0.010 \\
(-0.11)\end{array}$ & $\begin{array}{c}0.348^{* * * *} \\
(3.52)\end{array}$ \\
\hline AIC & 3489.65 & 3488.98 & 1968.88 & 1691.31 \\
\hline $\mathrm{N}$ & 3092 & 3092 & 1538 & 1554 \\
\hline
\end{tabular}

Note: Because the environmental information of the explained variable is disclosed as a discrete data variable, the ologit regression analysis method is adopted; ***,**, indicate the significance level of $1 \%, 5 \%$, and $10 \%$, respectively, and the $\mathrm{z}$-values in parentheses.

results, this paper adds two control variables, assetliability ratio, and property rights of the enterprise, to test the robustness of the conclusions. As can be seen from Table 5, in Model 1, the regression coefficient between performance pressure and environmental information disclosure is -0.099 , and is significantly negative based on $10 \%$, which proves Hypothesis 1 . The results of model 2 show that the regression coefficient of the interaction term between parent's shareholding ratio and performance pressure is 0.133 , and is significantly positive based on $5 \%$. Hypothesis 2 is verified. The results of model 3 and model 4 show that in the context of a lower degree of executives' synergy allocation of parent and subsidiary corporations, the regression coefficient of the interaction term between parent company's shareholding ratio and performance pressure is 0.348 , and is significantly positive based on $1 \%$. Hypothesis 3 is also verified. This shows that the conclusion of this paper is still robust after considering the financial status and property rights of the enterprise. 


\section{Research Conclusions and Enlightenment}

\section{Research Conclusions}

Based on the background that Chinese society is paying more and more attention to environmental protection, this article explores the attitudes of the executives of listed companies to environmental information disclosure when facing performance pressures within the framework of enterprise groups. The empirical results show:

Firstly, the performance pressure of listed companies has a positive impact on environmental information disclosure. That is, the greater the performance pressure of listed companies, the stronger the motivation of executives to disclose environmental information in order to prevent the decline in performance from threatening personal income and job stability, and to meet the current public's demands for environmental protection and governance.

Secondly, there is a moderating effect of parent company ownership on the relationship between performance pressure and environmental information disclosure, the specific performance is: the higher the shareholding ratio of the parent company, the weaker the positive impact of performance pressure on environmental information disclosure. That is to say, the higher the shareholding ratio of the parent company, the stronger the supervision consciousness and motivation to the listed companies, and the more obvious the convergence effect of interests, which strengthens the supervision motivation and ability to the executives of the listed companies, promotes the listed companies to face the pressure of performance, and weakens the tendency to engage in non-productive activities.

Thirdly, group the executives' synergy allocation of parent and subsidiary corporations according to the degree of synergy to test the differentiation of the parent company's shareholding adjustment effect. The results show that the executives' synergy allocation of parent and subsidiary corporations will affect the moderating effect of the parent company' $s$ shareholding. The specific manifestation is: in the context of a lower degree of executives' synergy allocation of parent and subsidiary corporations, the parent company's shareholding has a stronger effect on weakening the positive correlation between listed companies' performance pressure and environmental information disclosure.

\section{Theoretical Contribution}

First, this study is like most literature in the definition and measurement of performance pressure, but it is different from the performance dilemma that the existing literature focuses on factors such as R\&D tendency, investment level, workplace deception, and organizational unethical behavior. The research explains the response of listed companies in the performance dilemma through a pressure perspective, and analyzes the decision-making tendency of listed company executives based on the demand of shifting pressure, which is a supplement to the pressure theory and behavioral agency theory.

Secondly, this research has a more in-depth analysis and understanding of the motivations of listed companies for environmental information disclosure. The research proves that listed companies use environmental information disclosure to relieve pressure when facing performance pressure, and proves environmental information from the side. Disclosure is a non-productive method. From the perspective of listed company executives, strengthening environmental information disclosure also meets the current public and other core stakeholders' concerns and demands on the environmental governance of listed companies.

Finally, based on the enterprise group, which is an intermediate organization between market and enterprise, this study further discusses the role of parent company's shareholding in identifying and supervising the motivation of transferring pressure of listed company executives, and introduces the special governance element of executives' synergy allocation of parent and subsidiary corporations, which not only clarifies the internal logic of listed company executives' performance pressure and environmental information disclosure, but also enriches the relevant literature in the field of enterprise group governance.

\section{Managerial Implications}

Firstly, the study clarified that the executives of listed companies will have the motivation to engage in unproductive actions when facing performance pressure, and executives may use this to relieve performance pressure. In other words, if a listed company cannot achieve its expected performance goals in the short term, and its operating performance will affect its personal income and job stability, under pressure, it will choose to transfer the pressure of evaluation through environmental information disclosure, this kind of decision-making with a tendency to avoid is bound to be detrimental to the long-term development of the enterprise. In fact, no matter whether the pressure comes from the company itself or external uncontrollable factors, the executives of listed companies should continuously improve their own management and management capabilities and quality, and find ways to relieve them in the face of performance pressure. For example, managers can make changes to the enterprise to improve the current situation [39], and use nonproductive activities to transfer assessment goals and relieve pressure that does not meet the requirements of sustainable development [40]. At the same time, parent companies and external investors should moderately slow down their pursuit of short-term interests, and the assessment of listed companies and executives should shift to long-term and non-economic goals. Executives 
of listed companies should be encouraged to take a long-term perspective of corporate development and it can reduce the worries caused by the performance pressure, and have more confidence and courage to make suggestions for the long-term development of the company [41].

Secondly, it can be concluded from the conclusion that the parent company's shareholding and executives' synergy allocation of parent and subsidiary corporations within the framework of enterprise groups can supervise the decision-making of listed companies, and enable listed company executives to weigh the effects of shifting performance pressure, thereby affecting the tendency to implement environmental information disclosure. As a special governance mechanism for corporate groups, executives' synergy allocation of parent and subsidiary corporations can supervise the executives of the listed company to a certain extent, concurrent executives can report the actual operating conditions of the listed company to the parent company. The existence of this kind of information channel will restrict the motives of listed company executives to implement non-productive behaviors, prompting listed company executives to face up to the status quo of business operations and use their own management capabilities to use productive methods to alleviate their difficulties. This also further shows that the special arrangement of the executives' synergy allocation of parent and subsidiary corporations has a certain driving effect on improving the corporate governance efficiency and promoting the healthy development of the corporate group. It is necessary for the corporate group to appropriately promote this governance mechanism.

\section{Research Limitations and Future Prospects}

First, this paper only uses the data of listed companies in China's manufacturing industry for analysis, and classifies them according to the disclosure content of CSMAR. In the future, more comprehensive classification methods can be explored, and a more scientific and richer index system can be constructed to provide more reliable data support for future research. Secondly, due to the time lag in the release of corporate environmental information disclosure data in CSMAR database, this paper uses the data from 2014 to 2017 for analysis. Future research can further improve the timeliness of environmental information disclosure data. Finally, this paper uses parent-subsidiary corporate executive collaboration as a moderating variable. Given the availability of relevant data, this paper only takes 773 companies to conduct research. Future research can further improve the sample size and make a more scientific measurement of the data of executive collaboration.

\section{Acknowledgements}

The authors gratefully acknowledge the support from National Natural Science Foundation of China (grant no.71972117; 71602099), Shandong Provincial Natural Science Foundation, China (grant no. ZR2018QG003), Taishan scholars (grant no. tsqn202103095).

\section{Conflict of Interest}

The authors declare no conflict of interest.

\section{References}

1. ZOU H., XIE X, QI G., YANG M. The heterogeneous relationship between board social ties and corporate environmental responsibility in an emerging economy. Business Strategy and the Environment. 28 (1), 40, 2019.

2. CHEN X., ZHANG J., ZENG H. Is corporate environmental responsibility synergistic with governmental environmental responsibility? Evidence from China. Business Strategy and the Environment. 29 (8), 3669, 2020.

3. CHEN J.C., CHO C.H., PATTEN D.M. Initiating disclosure of environmental liability information: An empirical analysis of firm choice. Journal of Business Ethics. 125, 681, 2014.

4. DEEGAN C., RANKIN M. Do Australian companies report environmental news objectively?. Accounting Auditing \& Accountability Journal. 9 (2), 50, 1996.

5. YIN H., LI M., MA Y., ZHANG Q. The relationship between environmental information disclosure and profitability: A comparison between different disclosure styles. International journal of environmental research and public health. 16 (9), 1556, 2019.

6. YANG Y., WEN J., LI Y. The impact of environmental information disclosure on the firm value of listed manufacturing firms: evidence from China. International Journal of Environmental Research and Public Health. 17 (3), 916, 2020.

7. BALDINI M., DAL M.L., LIBERATORE G., MAZZI F., TERZANI S. Role of country-and firm-level determinants in environmental, social, and governance disclosure. Journal of Business Ethics. 150 (1), 79, 2018.

8. FITRI E.R., SAVITRI E., AL A.L. Influence of foreign ownership, ownership concentrated, and environmental disclosure to firm value. Indonesian Journal of Economics, Social, and Humanities. 1 (2), 91, 2019.

9. HUGHES S.B., ANDERSON A., GOLDEN S. Corporate environmental disclosures: are they useful in determining environmental performance? Journal of accounting and public policy. 20 (3), 217, 2001.

10. AHMADI A., BOURI A. The relationship between financial attributes, environmental performance, and environmental disclosure. Management of Environmental Quality: An International Journal. 28, 490, 2017.

11. ANDRIKOPOULOS A., KRIKLANI N. Environmental disclosure and financial characteristics of the firm: The case of Denmark. Corporate Social Responsibility and Environmental Management. 20 (1), 55, 2013.

12. QIU Y., SHAUKAT A., THARYAN R. Environmental and social disclosures: Link with corporate financial 
performance. The British Accounting Review. 48 (1), 102, 2016.

13. CLARKSON P.M., FANG X., LI Y., RICHARDSON G. The relevance of environmental disclosures: Are such disclosures incrementally informative?. Journal of Accounting and Public Policy. 32 (5), 410, 2013.

14. MENG X.H., ZENG S.X., SHI J.J., QI G.Y., ZHANG Z.B. The relationship between corporate environmental performance and environmental disclosure: An empirical study in China. Journal of environmental management. 145, 357, 2014.

15. NOR N.M., BAHARI N.A.S., ADNAN N.A., KAMAL S.M.Q.A.S., ALI I.M. The effects of environmental disclosure on financial performance in Malaysia. Procedia Economics and Finance. 35, 117, 2016.

16. CHEN S.H., LU C.C., JIANG G.S., WANG Y.R. The influence of political promotion of state-owned enterprise executives on M\&A behavior - An empirical study based on the theory of enterprise growth pressure. Management World. 9, 125-, 2015.

17. JENSEN, M.C., MECKLING W.H. Theory of the firm: managerial behavior, agency costs and ownership structure. Journal of Financial Economics. 3 (4), 305-360, 1976.

18. ZHANG Y., GIMENO J. Earnings pressure and competitive behavior: Evidence from the US electricity industry. Academy of Management Journal. 53 (4), 743, 2010.

19. BHOJRAJ S., LIBBY R. Capital market pressure, disclosure frequency-induced earnings/cash flow conflict, and managerial myopia. The Accounting Review. 80 (1), $1,2005$.

20. VENARD B., HANAFI M. Organizational isomorphism and corruption in financial institutions: Empirical research in emerging countries. Journal of Business Ethics. 81 (2), 481, 2008.

21. HUANG J., ZHOU C.N. An empirical study on the impact of ownership structure and management behavior on environmental information disclosure-empirical evidence from heavy pollution industries in shanghai stock market. China Soft Science. 1, 133, 2012.

22. GAUR S.S., BATHULA H., SINGH D. Ownership concentration, board characteristics and firm performance. Management Decision. 53 (5), 911, 2015.

23. NGUYEN T., LOCKE S., REDDY K. Ownership concentration and corporate performance from a dynamic perspective: Does national governance quality matter? International Review of Financial Analysis. 41, 148, 2015.

24. FRIEDMAN N.P., MIYAKE A., ALTAMIRANO L.J., CORLEY R.P., YOUNG S.E., RHEA S.A., HEWITT J.K. Stability and change in executive function abilities from late adolescence to early adulthood: A longitudinal twin study. Developmental psychology. 52 (2), 326, 2016.

25. PARRINO R., SIAS R.W., STARKS L.T. Voting with their feet: Institutional ownership changes around forced CEO turnover. Journal of financial economics. 68 (1), 3, 2003.

26. YERMACK D. Shareholder voting and corporate governance. Annual. Review of Financial Economics. 2 (1), 103, 2010.
27. MING Z.W., JIE Z. Supervision invalidation analysis resulting from information asymmetry in parentsubsidiary companies. Industrial Engineering Journal. 12 (5), 31, 2009

28. XU P., CHEN Z.J., MA P.C. Coordination of senior executives of parent and subsidiary companies: forms of expression, theoretical Logic, and Integration Research Framework. Economic and Management Review. 36 (05), $56,2020$.

29. WANG N., WANG Y. Does parenting matter in subsidiary innovation in emerging economies? Exploring the role of parent superior competitiveness in affecting subsidiary contextual ambidexterity. International Business Review. 101673, 2020.

30. NAS T.I., KALAYCIOGLU O. The effects of the board composition, board size and CEO duality on export performance: Evidence from Turkey. Management Research Review. 39 (11), 1374, 2016.

31. JENSEN M.C., MECKLING W.H. Theory of the firm: managerial behavior, agency costs and ownership structure. Journal of Financial Economics. 3 (4), 305, 1976.

32. WISEMAN J. An evaluation of environmental disclosures made in corporate annual reports. Accounting Organizations \& Society. 7 (1), 53, 1982.

33. GOMEZ M.W.L.R. A behavioral agency model of managerial risk taking. Academy of Management Review. 23 (1), 133, 1998.

34. PAUL P., MITRA P. Analysis of the effect of working capital management on profitability of the firm: evidence from Indian steel industry. Asia Pacific Journal of Management Research \& Innovation. 14, 32, 2018.

35. LIU Q., TIAN G. Controlling shareholder, expropriations, and firm's leverage decision: Evidence from Chinese nontradable share reform. Journal of Corporate Finance. 18, 782, 2012

36. BRICKLEY J.A., COLES J.L., JARRELL G. Leadership structure: separating the CEO and chairman of the board. Journal of Corporate Finance. 3 (3), 189, 1997.

37. SHER P.J., YANG P.Y. The effects of innovative capabilities and R\&D clustering on firm performance: the evidence of Taiwan's semiconductor industry. Technovation. 25 (1), 33, 2005.

38. FU T.W., KE M.C., HUANG Y.S. Capital growth, financing source and profitability of small businesses: evidence from Taiwan small enterprises. Small Business Economics. 18 (4), 257, 2002.

39. LABIANCA G., FAIRBANK J.F., ANDREVSKI G. Striving toward the future: aspiration-performance discrepancies and planned organizational change. Strategic Organization. 7, 433, 2009.

40. MERINO E., MANZANEQUE-LIZANO M., SANCHEZARAQUE J. Sustainability and corporate governance: transparency and excessive directors' remuneration in listed companies during the global financial crisis. Sustainability. 12, 158, 2020.

41. RASHID A. Managerial ownership and agency cost: evidence from Bangladesh. Journal of business ethics. 137 (3), 609, 2016. 